Seção: Políticas públicas - Ensaio dissertativo

\title{
A TRAJETÓRIA DA EDUCAÇÃO DE JOVENS E ADULTOS NO BRASIL
}

THE TRAJECTORY OF YOUTH AND ADULT EDUCATION IN BRAZIL

EL CAMINO DE LA EDUCACIÓN DE JÓVENES Y ADULTA EN BRASIL

\author{
Lenir Keller \\ Mestre em Ensino de Humanidades e Linguagens \\ Universidade Franciscana - UFN \\ E-mail: lenirkeller@yahoo.com.br \\ Orcid: https://orcid.org/0000-0001-7414-526X
}

\author{
Elsbeth Léia Spode Becker \\ Doutora em Agronomia \\ Universidade Franciscana - UFN \\ E-mail: elsbeth.geo@gmail.com \\ Orcid: https://orcid.org/0000-0002-9867-1835
}

\begin{abstract}
RESUMO
Este ensaio discorre sobre fatos relevantes que compõem a história da Educação de Jovens e Adultos no Brasil por meio de um levantamento documental e bibliográfico da literatura pertinente, das políticas públicas, da legislação desde o Brasil Colônia até a atualidade, com a intenção de compreender a evolução da modalidade através do tempo, nos diferentes momentos históricos, e os desdobramentos no campo educacional. Foi baseado, principalmente, nas obras de Gadotti (2009), Di Pierro (2005) e Di Pierro e Haddad (2000, 2015), que tratam da trajetória da Educação de Jovens e Adultos (EJA) no país, contextualizando-a no tempo e no cenário político-econômico e social, acrescidas, ainda, de análises sobre a conjuntura internacional e perspectivas para a modalidade na pós-modernidade. Pôde-se inferir que o pensamento em prol da EJA e sua qualidade de ensino exigem flexibilidade, maturidade psicológica, criatividade e complexidade cognitiva, na medida em que se busca atender às características e qualidades de desenvolvimento e de cultura dos jovens e adultos, às suas histórias de vida e contextos sociais.
\end{abstract}

Palavras-chave: Legislação. Contextualização. Finalidades. Perspectivas.

\begin{abstract}
This essay discusses relevant facts that compose the history of Youth and Adult Education in Brazil through a documentary analysis and bibliographic research of the pertinent literature, public policies and legislation from the time of Brazil Colony to the present. The objective was to understand the evolution of the EJA modality along the years, in the different historical moments and the developments in the educational field. The present study was based mainly on the work of Gadotti (2009), Di Pierro (2005) and Di Pierro and Haddad (2000, 2015) who deal with the trajectory of Youth and Adult Education in the country, contextualize it in time as well as in the political, economic and social scenario and analyse the international conjuncture and perspectives for the modality in post-modernity. It could be inferred that the thinking in favor of EJA and its teaching quality requires flexibility, psychological maturity, creativity and cognitive complexity, as it seeks to meet the characteristics and qualities of development and culture of young people and adults, their life stories and social contexts.
\end{abstract}

Keywords: Legislation. Contextualization. Purposes. Perspectives.

\section{RESUMEN}

El ensayo discurre sobre hechos relevantes que conforman la historia de la Educación de Jóvenes y Adultos en Brasil a través del análisis documental e investigación bibliográfica de literatura relevante, políticas públicas, legislación desde la Colonia Brasil hasta el presente, con la intención de comprender la evolución de la modalidad a través del tiempo, en los diferentes momentos históricos y los desarrollos 
Seção: Políticas públicas - Ensaio dissertativo

en el campo educativo. El marco teórico se basó principalmente en los trabajos de Gadotti (2009), Di Pierro (2005) y Di Pierro y Haddad $(2000,2015)$ que tratan de la trayectoria de la Educación de Jóvenes y Adultos (EJA) en el país, contextualizándolo en el tiempo y en el escenario político, económico y social, además del análisis de la coyuntura internacional y las perspectivas de la modalidad en la posmodernidad. Se podría inferir que pensar a favor de la EJA y su calidad de enseñanza requiere flexibilidad, madurez psicológica, creatividad y complejidad cognitiva, ya que busca satisfacer las características y cualidades del desarrollo y la cultura de los jóvenes y adultos, sus historias de vida y contextos sociales.

Palabras clave: Legislación. Contextualización. Propósitos. Perspectivas.

\section{INTRODUÇÃ̃O}

A Educação de Jovens e Adultos (EJA) foi instituída legalmente no Brasil como modalidade de ensino, Fundamental e Médio, em 1996, com a aprovação da Lei de Diretrizes e Bases da Educação Nacional, n 9394/96 (BRASIL, 1996b), destinada àqueles que não estudaram na idade escolar própria, em atendimento à demanda de jovens e adultos analfabetos, à baixa taxa de escolaridade e ao atraso escolar, cujos índices, historicamente, compõem a realidade educacional do nosso país.

Este estudo tem como objetivo estabelecer a contextualização da trajetória da EJA e sua importância na educação do Brasil. Para tanto, procurou-se investigar as primeiras iniciativas voltadas para a alfabetização de jovens e adultos desde o Período Colonial, passando pelo Império, pela República até a contemporaneidade. Na sequência, foi realizado um inventário das leis e dos programas que efetivaram a EJA no Brasil, a partir de 1996, evidenciando a sua abrangência e finalidades. Também, foram levantadas abordagens de autores e comentadores, Gadotti (2009), Di Pierro (2005) e Di Pierro e Haddad (2000, 2015), que discutem o contexto dessa modalidade de educação no país, os avanços alcançados, as fragilidades existentes e as projeções futuras.

O estudo foi dividido em sete seções. A primeira, "Introdução", apresenta a proposta da investigação. A segunda seção, "Brasil Colônia e Império: Catequização e Ensino de Ofícios para Adultos", refere-se às iniciativas de alfabetização para adultos, engendrada pelos jesuítas, para atender os filhos dos portugueses recém-imigrados e catequizar a população nativa, nos períodos do Brasil colonial e imperial. Na terceira seção, "A educação para adolescentes e adultos na República: ações incipientes e adequação às demandas político-econômicas”, são retomados aspectos sociais e econômicos que foram determinantes para as finalidades educacionais do segmento em questão e o surgimento de movimentos sociais em contraponto ao cenário político, porém sufocados com o golpe militar.

Na quarta seção, "Mobilizações internacionais para a educação de adultos: convergência para celebração de acordos e metas", traça-se um esboço dos movimentos internacionais voltados 
Seção: Políticas públicas - Ensaio dissertativo

para a promoção das garantias individuais, entre elas, a instrução. A quinta seção, "Constituição Cidadã: a Educação de Jovens e Adultos como direito humano", discorre sobre os marcos legais que constituíram a modalidade como proposta de restauração do direito à escolaridade, acesso aos bens sociais, exercício da cidadania e oportunidade de atualização permanente. A sexta seção, "Programas federais voltados para a Educação de Jovens e Adultos", elenca os principais programas para a modalidade, incluindo desde a alfabetização até a expansão de ofertas profissionalizantes a partir de 2005. E, por fim, na sétima seção, são apresentadas algumas considerações finais, enfocando os desafios presentes e futuros para a Educação de Jovens e Adultos.

\section{BRASIL COLÔNIA E IMPÉRIO: CATEQUIZAÇÃO E ENSINO DE OFÍCIOS PARA ADULTOS}

A proposta de uma educação para jovens e adultos no Brasil se iniciou junto com a história do país, no período colonial, em 1549, com a chegada dos jesuítas em Salvador, onde edificaram a primeira escola elementar. Aos jesuítas, foi delegada a tarefa de cuidar da educação para atender os filhos dos portugueses recém-chegados, propagação da fé católica e da cultura portuguesa, sendo uma das tarefas catequizar os índios, com o objetivo claro de expansão religiosa, aliado aos interesses de consolidação dos processos de colonização do governo imperial e da consolidação da cultura portuguesa:

\footnotetext{
O que representava a alfabetização para os jesuítas a ponto de quererem, desde o início, alfabetizar os índios, quando nem em Portugal o povo era alfabetizado? Mais do que o resultado dessa intenção, interessante é observar a mentalidade. As letras deviam significar adesão plena à cultura portuguesa (PAIVA, 2000, p. 43).
}

Posteriormente, os jesuítas passaram a ensinar regras para o convívio social e atividades profissionais aos índios e também para os escravizados, porque precisavam de mão de obra mais preparada para o exercício de funções em armazéns, engenhos e nas fazendas. Portanto, o acesso à escolarização foi ofertado aos índios e escravizados jovens e adultos com três objetivos claros por parte da coroa portuguesa: catequização, subjugação à cultura portuguesa e formação de mão de obra conforme as necessidades da economia do período colonial.

Durante dois séculos, os jesuítas fundaram colégios e foram os responsáveis pela educação desenvolvida nesse período, unindo interesses da corte e religiosos: formação religiosa e escolarização primária, evoluindo para o ensino clássico. Verifica-se, portanto, que os jesuítas tiveram um papel preponderante para além da difusão do evangelho, pois 
[...] tais educadores transmitiam normas de comportamento e ensinavam os ofícios necessários ao funcionamento da economia colonial, inicialmente aos indígenas e, posteriormente, aos escravos negros. Mais tarde, se encarregaram das escolas de humanidades para os colonizadores e seus filhos (DI PIERRO; HADDAD, 2000, p. 109).

Porém, com a expulsão dos jesuítas em 1759, a estrutura educacional existente passou por mudanças, sendo, então, assumida pelo governo, resultando em descontinuidade em termos de finalidades e organização, como descrevem Haddad e Di Pierro (2000, p. 109): "Com a desorganização do sistema de ensino produzido pela expulsão dos jesuítas do Brasil em 1759, somente no Império voltaremos a encontrar informações sobre ações educativas no campo da educação de adultos".

Mesmo com a chegada da família imperial ao Brasil, em 1808, e a consequente elevação do status político do Brasil de Colônia a Reino Unido de Portugal, as alterações e a expansão do sistema educacional destinaram-se à elite, com foco no ensino superior. A Constituição de 1824 previu a instrução primária gratuita a todos os cidadãos, portanto, e por extensão legal, para jovens e adultos. Dez anos depois, através do Ato Adicional de 1834, passou-se a responsabilidade para as províncias, para que se incumbissem da educação de todos, ficando o Império com a educação superior.

Devido às dificuldades financeiras das províncias, a referida lei não foi cumprida, ou seja, a educação continuou acessível para poucos, muito menos ainda para jovens e adultos, efetivando-se na prática a distância entre o direito legal e a garantia de acesso. Como se vê,

Essa distância entre o proclamado e o realizado foi agravada por outros fatores. Em primeiro lugar, porque, no período do Império, só possuía cidadania uma pequena parcela da população pertencente à elite econômica à qual se admitia administrar a educação primária como direito, do qual ficavam excluídos negros, indígenas e grande parte das mulheres. Em segundo, porque o Ato Adicional de 1834, ao delegar a responsabilidade por essa educação básica às Províncias, reservou ao governo imperial os direitos sobre a educação das elites, praticamente delegando à instância administrativa com menores recursos o papel de educar a maioria mais carente (HADDAD; DI PIERRO, 2000, p. 109).

Em 17 de fevereiro de 1854, através do Art. 71 do Decreto n ${ }^{\circ} 1331$-A, de autoria do Ministro do Império, Couto Ferraz, que regulamentava o ensino primário e secundário do Município da Corte (Rio de Janeiro).

Com isso, o Governo Imperial abriu possibilidades para as escolas que tivessem mais de um professor atender adultos e que assim quisessem, duas vezes por semana, domingos e feriados, como segue: 
Quando uma escola do segundo grau tiver dois professores, serão estes obrigados, alternadamente, por mês ou por ano, a ensinar as matérias da instrução primária duas vezes por semana, nas horas que lhes ficarem livres, ainda que seja em domingos e dias santos, aos adultos que para esse fim se lhes apresentarem (BRASIL, 1854, Art. 71).

O teor do conteúdo do Artigo 71 deixa claro que há necessidade de alfabetizar adultos, porém a obrigatoriedade do Estado de promover os meios e as condições se restringiu para quando houvesse disponibilidade. Esses adultos seriam homens pobres analfabetos, ocupados em trabalhar para seu sustento durante o dia e que receberiam a instrução primária, uma vez que o país estava se organizando, apresentava crescimento econômico naquele período, e a consequente demanda de trabalhadores mais preparados ficava evidente.

Já o Decreto nº 7031- A, de 6 de setembro de 1878, publicado pelo Ministro dos Negócios do Império, Carlos Leôncio da Silva Carvalho, tinha como finalidade única organizar a oferta de educação pública para adultos como instrução primária em escolas para o sexo masculino, tendo direito de frequentá-las homens livres, maiores de 14 anos, vacinados e saudáveis, conforme consta nos Art. $1^{\circ}$ e $5^{\circ}$.

No ano seguinte (1879), o ministro, Carlos Leôncio da Silva Carvalho, completou o projeto educacional do Império, propondo a Reforma do Ensino Primário, Secundário e Superior, por meio do Decreto $\mathrm{n}^{\mathrm{o}}$ 7.247, de 19 de abril de 1879, que deu origem aos Pareceres/Projetos de Rui Barbosa, os quais permitiam a frequência de escravos nas escolas e referendavam o ensino primário destinado aos adultos. O segundo parágrafo do Art. $2^{\circ}$ do Decreto $n^{\circ} 7.247 / 1879$ assim estabelecia:

Os meninos que atingirem a idade de 14 anos, antes de haverem concluído o estudo das disciplinas mencionadas no princípio deste artigo, são obrigados a continuá-lo, sob as penas estabelecidas, nas paróquias onde houver escolas gratuitas para adultos (BRASIL, 1879 , Art. $\left.2^{\circ}, \S 2^{\circ}\right)$

Para a época, a reforma foi bastante ousada e pretendia modernizar e ampliar a oferta de oportunidades educacionais. No entanto, os indicadores do período mostraram que pouco do almejado foi alcançado, como mencionam e Haddad e Di Pierro 2000, p.109 “[...] chegaríamos em 1890 com o sistema de ensino atendendo apenas 250 mil crianças, em uma população total estimada em 14 milhões. Ao final do Império, 82\% da população com idade superior a cinco anos era analfabeta".

Diante do exposto, é possível inferir a ideia de que a educação destinada a jovens e adultos, nos Períodos Colonial e Imperial, destinava-se ao ensino de ofícios em atendimentos às demandas de trabalho de cada período. 


\section{A EDUCAÇÃO PARA ADOLESCENTES E ADULTOS NA REPÚBLICA: AÇÕES INCIPIENTES E ADEQUAÇÃO ÀS DEMANDAS POLÍTICO-ECONÔMICAS}

Com o advento da República e a promulgação da Primeira Constituição do sistema republicano de governo, marcando a transição da Monarquia para a República, poucas mudanças ocorreram na educação brasileira, seguindo-se um quadro de exclusão, analfabetismo e atendimento às elites, conforme as palavras de Moura: "Com a proclamação da República, mesmo o país passando por transformações estruturais no poder político, o quadro educacional não sofreu mudanças significativas. [...] continuava privilegiando as classes dominantes" MOURA, 2003, p.31). Destaca-se que a Constituição de 1891 impedia de votar analfabetos e mendigos, mesmo sendo a maioria da população iletrada. Na época, com a instituição do federalismo, as províncias passaram a ser estados, cabendo-lhes a tarefa de promover o ensino primário, e ao governo federal, o ensino secundário e superior. Embora reformas educacionais tivessem sido adotadas, poucos resultados se obtiveram, sendo a questão financeira uma das dificuldades (HADDAD; DI PIERRO, 2000).

A ausência do Estado e os índices elevados de analfabetismo deram espaço à sociedade civil, que começou a se organizar, constituindo "ligas contra o analfabetismo", pois o censo realizado em 1920 apontava que $72 \%$ da população acima de cinco anos era analfabeta (HADDAD; DI PIERRO, 2000), somado ao fato de que não havia escolas suficientes para atendimento da demanda. Então, a preocupação com a qualidade da educação e a responsabilidade estatal é retomada.

A partir de 1930, com a chegada do capitalismo industrial no Brasil, a necessidade de viabilização de uma educação mais moderna, com conhecimentos e habilidades mínimas para sustentar na expansão industrial, predominou. Segundo Di Pierro e Haddad: "Essa inflexão no pensamento político-pedagógico ao final da Primeira República está associada aos processos de mudança social inerentes ao início da industrialização e à aceleração da urbanização no Brasil" (HADDAD; DI PIERRO, 2000, p. 110).

No entanto, as mobilizações sociais, movimentos de educadores e debates políticos manifestavam-se em favor de uma educação como direito social para todos, gratuita, obrigatória e dever do Estado, de caráter democrático, em contraponto às correntes dominantes que pensavam na ordem e no progresso econômico, culminando com a Revolução de 1930, que representou "um marco na reformulação do papel do Estado no Brasil”" (HADDAD; DI PIERRO, 2000, p. 110).

A Constituição de 1934 determinou a elaboração do Plano Nacional de Educação, o qual delineou as atribuições e atuação da União, dos Estados e Municípios na esfera educacional. 
Seção: Políticas públicas - Ensaio dissertativo

Também destinou uma receita para a manutenção e o desenvolvimento do ensino, através da criação do Fundo Nacional do Ensino Primário, e reafirmou o direito de todos e o dever do Estado para com a educação, a partir do Plano Nacional de Educação.

O objetivo da Constituição de 1934 era melhorar as condições de vida da grande maioria dos brasileiros, criando leis sobre educação, trabalho, saúde e cultura. Ampliou o direito de cidadania dos brasileiros, possibilitando à grande fatia da população, que até então era marginalizada do processo político do Brasil, participar então desse processo. A Constituição de 1934 trouxe, pois, uma perspectiva de mudanças na vida de grande parte dos brasileiros (BRASIL, 1934).

Porém, para a escolarização de adultos, apenas na década de 1940 foram sentidas mudanças, com a criação do Serviço Nacional de Aprendizagem Industrial (SENAI), em 1941, e o Serviço Nacional de Aprendizagem Comercial (SENAC), em 1946, em decorrência da necessidade de formação profissional para a efetivação do desenvolvimento econômico do país, ou seja, a educação de adultos entendida como educação profissional básica (FRIEDRICH et al., 2010).

Contudo, especialmente na segunda metade dos anos 40 do século XX, houve a efetivação de programas para jovens e adultos em decorrência da criação do Instituto Nacional de Estudos Pedagógicos (INEP) em 1938, cujos estudos apontaram para a necessidade de um fundo nacional com recursos destinados ao financiamento da Educação Primária e inclusão do Ensino Supletivo para adolescentes e adultos analfabetos (DI PIERRO; HADDAD, 2000), pois os índices de analfabetismo alcançavam 50\% da população em 1945 (FRIEDRICH et al., 2010).

A Constituição de 1946, sob influência das ideias liberais da Constituição de 1891 (BRASIL, 1891) e dos aspectos sociais de 1934 (BRASIL, 1934), reconheceu nos Artigos 66 e 77 a educação como direito de todos de forma gratuita, referindo-se ao ensino primário, de forma supletiva, destinado a adolescentes e adultos, com disciplinas obrigatórias e dois anos de duração, seguindo os mesmos princípios do ensino primário fundamental (BRASIL, 2000a).

Nesse período, no cenário internacional, era criada a Organização das Nações Unidas para Educação, Ciência e Cultura (UNESCO), a qual sublimava o papel primordial da educação, destacando a necessidade de políticas educacionais para alfabetização e escolarização de jovens e adultos (HADDAD; DI PIERRO, 2000). Em decorrência, no Brasil, em 1947, aconteceram o $1^{\circ}$ Congresso Nacional de Educação de Adultos e, em 1949, o Seminário Interamericano de Educação de Adultos, promovido pela UNESCO e Organização dos Estados Americanos (OEA), eventos relevantes para a educação voltada para jovens e adultos, como propulsores para a 
Seção: Políticas públicas - Ensaio dissertativo

organização, a ampliação da oferta de escolarização tanto no meio urbano quanto rural e a premência de metodologias diferenciadas para efetivação das ações (FRIEDRICH et al, 2010).

Ainda em 1947, foi estabelecido o Serviço de Educação de Adultos (SEA), ligado ao Departamento Nacional de Educação do Ministério da Educação e Saúde, tendo suas atividades encerradas em 1950, o qual difundiu campanhas para educação de adolescentes e adultos, contribuindo para a organização e difusão da oferta em estados e municípios. Mesmo assim, os indicadores continuavam apontando a precariedade do quadro educacional:

Devido às escassas oportunidades de acesso à escolarização na infância ou na vida adulta, até 1950, mais da metade da população brasileira era analfabeta, o que a mantinha excluída da vida política, pois o voto lhe era vedado (DI PIERRO; VÓVIO; ANDRADE, 2008, p. 25).

Para tentar resolver essa realidade, o Ministério da Educação e Cultura instituiu a Campanha Nacional de Educação Rural em 1952, e, em seguida, em 1958, foi criada a Campanha Nacional de Erradicação do Analfabetismo.

No entanto, conforme análise de Haddad e Di Pierro, houve uma redução do índice de analfabetismo no país, mas não necessariamente qualificação da escolarização:

Os esforços empreendidos durante as décadas de 1940 e 1950 fizeram cair os índices de analfabetismo das pessoas acima de cinco anos de idade para 46,7\% no ano de 1960 . Os níveis de escolarização da população brasileira permaneciam, no entanto, em patamares reduzidos quando comparados à média dos países do primeiro mundo e mesmo de vários dos vizinhos latino-americanos (HADDAD; DI PIERRO, 2000, p.111).

Como exigência da Constituição Federal de 1946, foi aprovada a Lei de Diretrizes e Bases da Educação Nacional no 4.024, em 20 de dezembro de 1961, após treze longos anos de disputas, legitimando as forças conservadoras e minimizando recursos, acesso à educação e oportunidades. A primeira Lei de Diretrizes e Bases da Educação Nacional (BRASIL, 1961) serviu para regularizar o sistema educacional no país, os conselhos estaduais de educação e a formação mínima exigida para professores, todavia, não produziu os desdobramentos esperados, e a preocupação com a escolarização de adolescentes e adultos ficou restrita à possibilidade de formação de classes especiais, no sentido de aceleração de estudos, para alunos com atraso escolar, e de realização de provas para conclusão e certificação correspondente ao curso ginasial (BRASIL, 2000a).

Nos períodos republicanos, da República Velha (1889-1930), Era Vargas (1930-1945) e República Populista (1946-1964), a educação pensada para adolescentes e adultos foi ponto de discussão e de medidas governamentais, mais como necessidade de escolarização para acompanhar as mudanças econômicas e políticas do país, do que como direito do cidadão 
Seção: Políticas públicas - Ensaio dissertativo

brasileiro e dever do Estado. Porém, em contraponto, serviu como base para a busca de mudanças futuras e mais profundas, focadas nos vieses pedagógico e social.

\subsection{OS MOVIMENTOS SOCIAIS E O COMPROMISSO COM UMA EDUCAÇÃO DE QUALIDADE PARA JOVENS E ADULTOS}

No período republicano, a sociedade brasileira viveu momentos de efervescência política e de organização das classes populares na busca de seus direitos face ao desenvolvimento industrial. $\mathrm{Na}$ verdade, as políticas de governo visavam a ampliar as ofertas educacionais com interesse na formação mais eficiente dos operários. Já o movimento operário buscava uma educação voltada para a emancipação, para ambos os sexos, e laica, ideais que foram concretizados com a criação das escolas modernas, as quais foram fundadas no período de 1894 a 1922 no país e "[...] destacavam-se pela aceitação da coeducação de classes e gêneros e pela educação integrada de jovens e adultos [...]" (FELTRIN, 2017, p. 72). As referidas escolas adotaram a pedagogia racional libertária, com a finalidade enfrentar o processo de dominação reproduzido pelas formas tradicionais de educação em favor da emancipação da pessoa, no entanto, à medida que foi percebido que a ideologia anarquista era predominante, estas passaram a ser perseguidas e fechadas. A educação para adultos também era promovida em outros espaços, como Centros de Cultura ou Estudos Sociais.

A realização do II Congresso Nacional de Educação de Adultos no Rio de Janeiro (1958), durante o governo de Juscelino Kubitschek, contribuiu para avolumar-se ainda mais a percepção de que a alfabetização e a escolarização de jovens e adultos demandavam uma pedagogia diferenciada, envolvida com o meio social e a realidade desses estudantes, contando com o apoio dos movimentos sociais como o Movimento de Educação de Base e o Movimento de Cultura Popular do Recife, bem como a participação de Paulo Freire, conforme são descritos na citação de Haddad e Di Pierro (2000, p. 113):

\footnotetext{
É dentro dessa perspectiva que devemos considerar os vários acontecimentos, campanhas e programas no campo da educação de adultos, no período que vai de 1959 até 1964. Foram eles, entre outros: o Movimento de Educação de Base, da Conferência Nacional dos Bispos do Brasil, estabelecido em 1961, com o patrocínio do governo federal; o Movimento de Cultura Popular do Recife, a partir de 1961; os Centros Populares de Cultura, órgãos culturais da UNE; a Campanha De Pé no Chão Também se Aprende a Ler, da Secretaria Municipal de Educação de Natal; e, finalmente, em 1964, o Programa Nacional de Alfabetização do Ministério da Educação e Cultura, que contou com a presença do professor Paulo Freire.
}

As iniciativas de 1961, dos Centros Populares de Cultura, coordenados pela União Nacional de Estudantes (UNE) com a utilização do método Paulo Freire, foram as mais promissoras para a concretude de processos de alfabetização emancipatórios, preocupados e centrados naqueles que 
Seção: Políticas públicas - Ensaio dissertativo

aprendem. Paulo Freire criou uma proposta inovadora de alfabetização que foi colocada em prática na cidade de Angicos, Rio Grande do Norte, onde foram alfabetizados 300 cortadores de cana de açúcar em apenas 45 dias.

O método vinculava a prática alfabetizadora ao exame de problemáticas que impediam ou dificultavam o acesso aos bens da própria cultura e à participação política; servia como meio para desvelar processos de opressão e dominação no mundo do trabalho e desigualdades das condições de vida dos brasileiros. (DI PIERRO; VÓVIO; ANDRADE, 2008, p.28).

Como o pensamento e a proposta de Paulo Freire para a alfabetização de adultos assumiram grande destaque na década de 60 do século XX, em 1963, ele foi designado responsável para a criação de um Programa Nacional de Alfabetização de Adultos (PNAA), o qual foi aprovado pelo Decreto 53.465, de 21 de janeiro de 1964 (BRASIL, 1964), que tinha como meta alfabetizar dois milhões de pessoas.

Cabe ressaltar que, mesmo com o exílio de Paulo Freire, o "paradigma freireano" e os princípios da Educação Popular, embasados na reflexão, diálogo, no entendimento do contexto pessoal e social, abordagem metodológica diferenciada, permaneceram vivos em iniciativas de igrejas e movimentos sociais (DI PIERRO; JÓIA; RIBEIRO, 2001).

\subsection{EDUCAÇÃO PARA JOVENS E ADULTOS APÓS O GOLPE DE 1964: RETORNO AO ASSISTENCIALISMO E CONSERVADORISMO}

Com o Golpe Militar no ano de 1964, todo o trabalho organizado pelos movimentos sociais foi desmantelado, inclusive com o exílio de Paulo Freire, sendo instalados novamente programas de cunho assistencialista e conservador para a alfabetização de adultos, como afirmam Haddad e Di Pierro (2000, p. 113): "No plano oficial, enquanto as ações repressivas ocorriam, alguns programas de caráter conservador foram consentidos ou mesmo incentivados [...]", entre eles a Cruzada ABC (Ação Básica Cristã), financiada pelo governo federal.

Diante da perpetuação de índices de analfabetismo, da baixa escolaridade da população brasileira e dos desconfortos ocasionados por esta realidade ao governo do regime militar, bem como diante das pressões internacionais, a Constituição de 1967 declarou a educação um direito de todos e estendeu a obrigatoriedade do ensino até os quatorze anos (BRASIL, 1967a). Também, nesse mesmo ano, através da Lei 5.379, de 15 de dezembro de 1967, foi instituído o Movimento Brasileiro de Alfabetização (MOBRAL), com a finalidade de erradicar o analfabetismo e propor a educação continuada de adolescentes e adultos" (BRASIL, 1967b). Nesse sentido, percebe-se que 


\begin{abstract}
Além da legitimação interna, esta iniciativa governamental também visava responder a orientações emanadas de agências internacionais ligadas à Organização das Nações Unidas, em especial a Unesco, que desde o final da Segunda Guerra vinham propugnado o valor do combate ao analfabetismo e da universalização de uma educação elementar comum como estratégia de desenvolvimento socioeconômico e manutenção da paz (DI PIERRO; JÓIA; RIBEIRO, 2001, p. 61).
\end{abstract}

Contando com recursos federais, parcerias com instituições privadas e religiosas para alcançar a meta de erradicar o analfabetismo no país em dez anos, o MOBRAL tornou-se uma campanha de massas.

Isso se deu pelo fato de ter sido implantado com três características: "paralelismo aos demais programas de alfabetização", "organização operacional descentralizada" e "centralização da direção do processo educativo" (HADDAD; DI PIERRO, 2000, p. 115), com propósitos de controle pedagógico do programa e manutenção da ordem vigente. Mesmo assim, segundo Friedrich et al. (2010), o MOBRAL, apesar dos rígidos mecanismos de controle e fartos recursos, não alcançou a meta proposta e foi extinto em 1985, período de redemocratização do país.

Em 1971, através da Lei de Diretrizes e Bases da Educação Nacional nº 5.692, de 11 de agosto de 1971, a educação para jovens e adultos foi contemplada com cinco artigos no Capítulo IV, os quais abordaram suas finalidades, a disposição para a formação profissional, a possibilidade de cursos a distância através de rádio, televisão, correspondência e outros meios de comunicação disponíveis na época, e a certificação através dos exames e cursos profissionalizantes (BRASIL, 1971).

O Art. 27 da lei em discussão determinou a oferta de cursos de aprendizagem para alunos de 14 a 18 anos, quando frequentando os anos finais do $1^{\circ} \mathrm{Grau}$, e de cursos intensivos de qualificação profissional para alunos do $2^{\circ}$ Grau (BRASIL, 1971), ou seja, a formação de mão de obra em atendimento às necessidades tecnicistas da expansão do parque industrial brasileiro. Há claramente o atrelamento dos princípios do ensino supletivo ao mercado de trabalho, com a urgente necessidade de formação de mão de obra, como concluem Haddad e Di Pierro (2000, p. 117): "Portanto, o Ensino Supletivo se propunha a recuperar o atraso, reciclar o presente, formando uma mão de obra que contribuísse no esforço para o desenvolvimento nacional, através de um novo modelo de escola".

Como consequência do Golpe Militar, os movimentos sociais se enfraqueceram, tendo a reestruturação do sistema educacional dado lugar aos domínios autoritários e centralizadores que muitas vezes serviram como meio de controle social e reprodução da ordem.

\title{
4 MOBILIZAÇÕES INTERNACIONAIS PARA A EDUCAÇÃO DE ADULTOS: CONVERGÊNCIA PARA CELEBRAÇÃO DE ACORDOS E METAS
}


Seção: Políticas públicas - Ensaio dissertativo

As mobilizações no mundo inteiro em defesa de uma educação de qualidade para jovens e adultos têm sido tema nas agendas internacionais, com destaque às Conferências Internacionais de Educação de Adultos (CONFINTEAs), realizadas no período de 1949 a 2009.

Embora as agendas internacionais não tenham a função nem o poder de determinar as ações dos governos para a implementação de programas voltados para a erradicação do analfabetismo e a promoção da elevação da taxa de escolaridade da população, apontam diretrizes para a efetivação de políticas públicas para o segmento.

\begin{abstract}
Mesmo não tendo caráter impositivo, acordos internacionais assinados pelos governos nacionais podem se constituir em instrumentos para que a sociedade civil - em cada país ou nas redes globais - exerça pressão para a garantia de direitos, mudança de leis e comportamentos, acesso a informações ou reivindicação de políticas públicas. As metas internacionais associadas a esses acordos direcionam a cooperação internacional bilateral e multilateral, estimulando governos nacionais a perseguir os compromissos para acessar tais recursos, responder às pressões ou evitar sanções externas (DI PIERRO; HADDAD, 2015, p. 200).
\end{abstract}

As CONFINTEAs surgiram na segunda metade do século XX com o objetivo de discutir e encontrar caminhos para enfrentamento do analfabetismo.

Para isso, firmou-se acordos e metas entre os países participantes, em direção à consolidação do direito à instrução obrigatória e gratuita, "no sentido do pleno desenvolvimento da personalidade humana e do fortalecimento do respeito pelos direitos humanos e pelas liberdades fundamentais", garantida no Art. XXVI da Declaração Universal dos Direitos Humanos (DUDH), proclamada pela Organização das Nações Unidas em 1948 (ONU BRASIL, 1948). Ao se reportar à importância das CONFINTEAs, Gadotti afirma que "a Confintea, de caráter intergovernamental, tem por objetivo a promoção da Educação de Adultos como política pública no mundo" (GADOTTI, 2009, p. 7).

A I CONFINTEA aconteceu na Dinamarca, em 1949, após o término da Segunda Guerra Mundial, tendo como preocupação a educação de pessoas adultas como instrumento de difusão dos direitos humanos fundamentais para a cultura da paz, em decorrência das atrocidades recémvivenciadas pela humanidade. A II Conferência, realizada em 1960, no Canadá, contemplou duas questões: "[...] a Educação de Adultos, concebida como uma continuação da educação formal, como educação permanente, e, de outro lado, a educação de base ou educação comunitária" (GADOTTI, 2009, p. 9).

No ano de 1972, a III CONFINTEA aconteceu no Japão, tendo como tema "A educação de adultos no contexto da educação ao longo de toda a vida", abrindo o debate sobre legislação, financiamento, profissionalização, pesquisa em Educação de Adultos, cooperação internacional. A referida conferência foi considerada "bastante produtiva [... e] ajudou a avançar nas discussões 
Seção: Políticas públicas - Ensaio dissertativo

sobre educação de adultos na perspectiva da educação ao longo da vida e sobre a centralidade da aprendizagem para esse processo" (IRELAND, 2014, p. 37).

Em 1985, na França, sob influência das recomendações sobre a Educação de Adultos da Conferência de Nairóbi, corrida em 1976, realizou-se a IV CONFINTEA, tendo como temas a educação permanente, o direito a aprender e o papel do Estado e das Organizações NãoGovernamentais (ONGs). Este evento contou com 800 participantes, sendo representados mais de 100 Estados membros e ONGs de todos os continentes.

A V CONFINTEA foi realizada na Alemanha em 1997 e teve o maior público: 1.300 participantes, representantes de 150 países e de 40 ONGs. Segundo Gadotti (2009), a V CONFINTEA deixou muitas "lições" que devem ser levadas em conta:

[...] a) reconhecer o papel indispensável do educador bem formado; b) reconhecer e reafirmar a diversidade de experiências; c) assumir o caráter público da EJA; d) ter um enfoque intercultural e transversal; e) a importância da EJA para a cidadania, o trabalho e a renda numa era de desemprego crescente; f) o reconhecimento da importância da articulação de ações locais; g) reconceituar a EJA como um processo permanente de aprendizagem; h) reafirmar a responsabilidade inegável do Estado diante da EJA; i) fortalecer a sociedade civil; j) reconhecer a EJA como uma modalidade da educação básica; k) resgatar a tradição de luta política da EJA pela democracia e pela justiça social (GADOTTI, 2009, p. 10).

Nessa Conferência, foi destacada a aprendizagem ao longo da vida como direito dos cidadãos e o reconhecimento da diversidade sociocultural e perspectiva de gênero. Foram aprovadas a "Declaração de Hamburgo", a adoção da "Agenda para o futuro", e a instituição da "Década Paulo Freire da Alfabetização"

A VI CONFINTEA foi realizada no Brasil, em Belém, Pará, no ano de 2009, tendo como lema "Aproveitando o poder e o potencial da aprendizagem e educação de adultos para um futuro viável" e contou com 1.125 participantes de 144 países. A VI CONFINTEA teve dois objetivos principais: a articulação da educação e aprendizagem e a efetivação de políticas públicas para a viabilização da educação de adultos. Também propôs ampliar o conceito de educação para adultos e vincular a aprendizagens significativas ao longo da vida, com vistas à inclusão social e construção de sociedades mais justas, solidárias e sustentáveis (IRELAND, 2014), "reafirmando compromissos para a EJA e estabelecendo novas estratégias para o seu desenvolvimento" (DI PIERRO E HADDAD, 2015, p. 201).

As mobilizações no mundo todo, com a realização de conferências, encontros, fóruns e pactos, constituem-se num movimento internacional de salvaguarda em prol da garantia de direitos das pessoas não escolarizadas ou com baixas taxas de escolarização. 
A participação do Brasil nas agendas internacionais, o crescente movimento mundial para a garantia do direito à educação de qualidade para crianças, jovens e adultos ao longo da vida, o olhar para o analfabetismo, para a mudança de paradigmas mundiais de igualdade, justiça social e sustentabilidade têm fortalecido a EJA como direito humano, embora os avanços sejam acanhados, ou seja,

\footnotetext{
A agenda internacional vem gradativamente ganhando relevância nos últimos anos no Brasil, não só pela intensificação do processo de globalização observado em todos os âmbitos da vida, como pelo papel que o país passou a desempenhar nos cenários regional e global. Apesar disso, o debate interno sobre essa agenda ainda é pequeno, em especial, no campo da educação e da EJA (DI PIERRO; HADDAD, 2015, p. 200).
}

Os debates internacionais no campo educacional delineiam perspectivas e induzem à definição de políticas nacionais e, no caso do Brasil, endossaram a necessidade de discutir e encaminhar a problemática de prover educação de pessoas jovens e adultas sem escolaridade ou com escolaridade reduzida.

\section{A CONSTITUIÇÃo CIDAdÃ: A EDUCAÇÃo DE JOVENS E ADULTOS COMO DIREITO HUMANO}

A aprovação da Constituição Federal em 1988 referendou anseios de mudança da população brasileira em direção à consolidação de uma sociedade de direitos, defendidos amplamente no período de redemocratização do país. Para a EJA, marcou um avanço significativo, com a garantia de oferta da educação básica obrigatória e gratuita também para jovens e adultos, conforme consta no Art. 208: “educação básica obrigatória e gratuita dos 4 (quatro) aos 17 (dezessete) anos de idade, assegurada inclusive sua oferta gratuita para todos os que a ela não tiveram acesso na idade própria” (BRASIL, 1988).

Em 1996, a Lei de Diretrizes e Bases da Educação Nacional (LDBEN), Lei nº 9394/96, abriu um capítulo para a EJA (BRASIL, 1996b). Na época, conforme o Instituto Brasileiro de Geografia e Estatística (IBGE), havia 15.560.260 pessoas analfabetas na população brasileira, ou seja, $14,7 \%$, e os índices de exclusão escolar, defasagem idade-série e repetência eram igualmente elevados (BRASIL, 1996a).

Como direito do cidadão e dever do Estado, a educação escolar pública deve ser garantida mediante acesso público e gratuito aos ensinos fundamental e médio para todos os que não os concluíram na idade própria. Detalhando mais sobre a EJA, o Art. 37 preconiza: “A educação de jovens e adultos será destinada àqueles que não tiveram acesso ou continuidade de estudos no ensino fundamental e médio na idade própria", sendo atualizado o presente artigo pela Lei 
Seção: Políticas públicas - Ensaio dissertativo

13.632/2018, com a visão da EJA ampliada para um instrumento para a educação e a aprendizagem ao longo da vida (BRASIL, 2018b).

Na LDBEN no 9.394/1996, a EJA é assegurada gratuitamente aos jovens e aos adultos, com oportunidades educacionais apropriadas, consideradas as características do alunado, seus interesses, condições de vida e de trabalho, o acesso e a permanência do trabalhador na escola, articulação com a Educação Profissional, cursos e exames supletivos, que compreenderão a base nacional comum do currículo, habilitando ao prosseguimento de estudos em caráter regular, destinados, no nível de conclusão do Ensino Fundamental, para os maiores de quinze anos (15) e, no nível de conclusão do Ensino Médio, para os maiores de dezoito (18), conforme consta no primeiro parágrafo do Art. 37 da LDBEN:

Os sistemas de ensino assegurarão gratuitamente aos jovens e aos adultos, que não puderam efetuar os estudos na idade regular, oportunidades educacionais apropriadas, consideradas as características do alunado, seus interesses, condições de vida e de trabalho, mediante cursos e exames (BRASIL, 1996b, Art. 37).

A partir desses marcos legais, o ensino voltado para jovens e adultos passou a ser institucionalizado e ter um espaço formal na educação brasileira, para superação das referências históricas de uma visão precária, utilitarista, compensatória e supletiva, em direção à sua consolidação como direito social e subjetivo e à responsabilização do Estado pela oferta da modalidade.

Em 2000, o Conselho Nacional de Educação e a Câmara de Educação Básica aprovaram o Parecer CEB n 11/2000, estabelecendo diretrizes curriculares nacionais para a Educação de Jovens e Adultos. No teor do parecer, constam reflexões sobre o quadro socioeducacional brasileiro que continuava a reproduzir excluídos, ou seja, jovens e adultos com atrasos ou sem a escolaridade obrigatória. A Educação de Jovens e Adultos passa a ter três funções. A primeira é a função reparadora, que diz respeito ao acesso aos direitos negados, como por exemplo, a uma escola de qualidade. A segunda função é equalizadora e remete à igualdade de oportunidades para jovens e adultos. Já a terceira, a função qualificadora ou permanente, abrange a atualização dos conhecimentos e o desenvolvimento do potencial humano por toda a vida. O referido parecer destaca que a EJA deve ter um modelo pedagógico próprio que atenda às necessidades de aprendizagem de jovens e adultos (BRASIL, 2000).

No mesmo ano, o Conselho Nacional de Educação publicou a Resolução CNE/CEB N ${ }^{\circ}$ 1, de 5 de julho de 2000 (BRASIL, 2000b), que trata das Diretrizes Curriculares Nacionais para a Educação de Jovens e Adultos, a partir do Parecer CNE/CEB 11/2000. A resolução destaca a necessidade de um modelo pedagógico próprio para a modalidade, em observância à identidade 
Seção: Políticas públicas - Ensaio dissertativo

inerente da Educação de Jovens e Adultos, considerando os perfis dos estudantes, as faixas etárias e os princípios da equidade e diferença, evocando a igualdade de direitos e respeito às diferenças nos processos de formação.

Em 2001, com a Lei $N^{\circ}$ 10.172, foi aprovado o Plano Nacional de Educação, justificando que "Os déficits do atendimento no ensino fundamental resultaram, ao longo dos anos, num grande número de jovens e adultos que não tiveram acesso ou não lograram terminar o ensino fundamental obrigatório" (BRASIL, 2001a, p. 37). Foram definidas e aprovadas 26 metas para a modalidade, contemplando erradicação do analfabetismo, ampliação e garantias da oferta e acesso à modalidade, promoção de provas e exames para certificação, produção de material didático-pedagógico adequado à clientela, financiamento e integração dos programas de educação de jovens e adultos com a educação profissional.

Para viabilizar a promoção de provas e exames para certificação, dispositivo previsto na LDBEN n $n^{\circ}$ 9.394/96 e BRASIL, foi instituído pela Portaria $n^{\circ} 2.270$, de 14 de agosto de 2002 (BRASIL, 2002a), o Exame Nacional de Certificação de Competências de Jovens e Adultos (ENCCEJA), que perdura até hoje, porém, sendo considerado como uma estratégia mais de certificação do que compromisso com a qualidade da formação de jovens e adultos. Para Rummert (2007, p. 45), o ENCCEJA “[...] vai ao encontro da valoração do "diploma” em detrimento do valor do conhecimento [...]. Sua finalidade é, assim, possibilitar a obtenção de certificados de conclusão de cursos e não propiciar as condições de acesso ao conhecimento".

Embora haja controvérsias sobre a efetividade dos planos decenais de educação no Brasil, a meta 26 do Plano Nacional de Educação de 2001 previu "incluir, a partir da aprovação do Plano Nacional de Educação, a Educação de Jovens e Adultos nas formas de financiamento da Educação Básica" (BRASIL, 2001a, p. 43). Em 2007, foi aprovado o Fundo de Manutenção e Desenvolvimento da Educação Básica e de Valorização dos Profissionais da Educação (FUNDEB), regulamentado pela Lei n ${ }^{\circ}$ 11.494/2007 (BRASIL, 2007), em substituição ao Fundo de Manutenção e Desenvolvimento do Ensino Fundamental e de Valorização do Magistério (FUNDEF), sendo que este último contemplava apenas o financiamento do ensino fundamental regular.

A inclusão da EJA no financiamento da educação favoreceu a oferta da modalidade, porém de forma desigual em relação ao cômputo geral da Educação Básica. Há questionamentos sobre fatores de ponderação, pois o percentual não é integral, inicialmente 0,7 do valor FUNDEB/aluno, bem como a limitação máxima de até $15 \%$ dos recursos destinados à modalidade de ensino. Atualmente, o fator de ponderação alcança 0,8 para Educação de Jovens e Adultos com avaliação no processo e 1,20 para Educação de Jovens e Adultos integrada à 
Seção: Políticas públicas - Ensaio dissertativo

Educação Profissional de nível médio com avaliação no processo. Dessa forma, torna-se mais atrativo financeiramente para as mantenedoras investirem em programas de ampliação em outras etapas e modalidades da Educação Básica, contando com o retorno do aporte de recursos legal e proporcionalmente previstos.

A EJA também foi contemplada com recursos em Programas Suplementares do Ministério da Educação, como a merenda escolar e livro didático. Em 2009, através da Lei no 11.947, que dispõe sobre o atendimento da merenda escolar para a educação básica, os alunos da EJA passaram a fazer parte do cômputo dos beneficiários do Programa Nacional de Alimentação Escolar - PNAE (BRASIL, 2009). No mesmo ano de 2009, foi aprovada a Resolução CD/FNDE $n^{\circ} 51$, de 16 de setembro de 2009, que dispõe sobre o Programa Nacional do Livro Didático para Educação de Jovens e Adultos (PNLD EJA), alterada pela resolução nº 22, de 7 de junho de 2013, a qual trata do Programa Nacional do Livro Didático (PNLD) para a Educação Básica e a Educação de Jovens e Adultos (BRASIL, 2013).

No ano de 2001, o Ministério da Educação lançou a Proposta Curricular para o Primeiro Segmento da Educação de Jovens e Adultos (BRASIL, 2001b) e, em 2002, a Proposta Curricular Para o Segundo Segmento da EJA. Este documento enfatiza a importância da observância das especificidades marcantes da modalidade para cumprimento das funções reparar, equalizar e qualificar, mas afirma que os objetivos educacionais são os mesmos do Ensino Fundamental e/ou Médio (BRASIL, 2002). Destaca que a identidade de um curso de EJA requer um olhar diferenciado, a valorização dos conhecimentos, dos interesses e das necessidades de aprendizagem dos alunos e a organização de propostas flexíveis que abarquem uma diversidade de temas. Quanto às diretrizes curriculares para a Educação de Jovens e Adultos/Ensino Médio, não há publicação de documentos por parte do Ministério e Educação.

Oito anos mais tarde, em 2010, o Conselho Nacional de Educação aprovou três pareceres sobre a EJA:

a) Parecer CNE/CEB n 4/2010, aprovado em 9 de março de 2010 - Diretrizes Nacionais para a oferta de educação para jovens e adultos em situação de privação de liberdade nos estabelecimentos penais (BRASIL, 2010a);

b) Parecer CNE/CEB n 6/2010, aprovado em 7 de abril de 2010 - Reexame do Parecer CNE/CEB n 23/2008, que instituiu Diretrizes Operacionais para a Educação de Jovens e Adultos - EJA, nos aspectos relativos à duração dos cursos e idade mínima para ingresso nos cursos de EJA; idade mínima e certificação nos exames de EJA; e Educação de Jovens e Adultos desenvolvida por meio da Educação a Distância (BRASIL, 2010b); 
c) Parecer $\mathrm{CNE} / \mathrm{CEB} \mathrm{N}^{\circ} 7 / 2010$, que trata das diretrizes curriculares nacionais gerais para a Educação Básica; a Educação de Jovens e Adultos é tida como forma de saldar uma dívida social, pois a defasagem educacional gera a exclusão social, devendo o resgate ser ofertado de forma sistemática e continuada. Também orienta sobre a necessidade de flexibilização do tempo, espaço e currículo, dando abertura para organização de percursos individualizados, conforme necessidades de aprendizagens. Sugere o desenvolvimento de competências para o trabalho e formação continuada específica para os professores.

Também em 2010, o Conselho Nacional de Educação e a Câmara de Educação Básica aprovaram duas resoluções normatizando as questões abordadas nos pareceres já abordados:

a) Resolução $\mathrm{n}^{\circ}$ 2, de 19 de maio de 2010, que trata das sobre as Diretrizes Nacionais para a oferta de Educação para Jovens e Adultos em situação de privação de liberdade nos estabelecimentos penais (BRASIL, 2010d);

b) Resolução $n^{\circ}$ 3/2010, de 15 de junho de 2010, que institui diretrizes operacionais para a Educação de Jovens e Adultos nos aspectos relativos à idade mínima para ingresso, duração dos cursos de EJA, certificação nos exames e normas de funcionamento da modalidade por meio da Educação a Distância (BRASIL, 2010d).

Em 2014, através da Lei no 13.005, foi aprovado o Plano Nacional de Educação para o decênio 2014/2024 (BRASIL, 2014), propondo, nas metas 8 e 9, elevar a escolaridade média da população, elevar a taxa de alfabetização da população com quinze anos ou mais para 93,5\% até 2015 e, até o final da vigência deste PNE, erradicar o analfabetismo absoluto e reduzir em 50\% a taxa de analfabetismo funcional. Como estratégias, citam a oferta gratuita da modalidade, busca da demanda ativa, programas suplementares de saúde e assistência social. Já na meta 10, é retomada a integração da EJA à educação profissional e propõe oferecer, no mínimo, 25\% das matrículas de educação de jovens e adultos, nos ensinos fundamental e médio, na forma integrada à educação profissional, conforme comentam Haddad e Di Pierro (2015, p. 213): “A ênfase na qualificação profissional da mão de obra marca também a abordagem conferida à EJA no segundo Plano Nacional de Educação (PNE), finalmente consignado na Lei n. 13.005/2014 após longos debates no Congresso".

Contudo, a realidade educacional brasileira continua com dados alarmantes. Segundo o Instituto Brasileiro de Geografia e Estatísticas (IBGE), na Pesquisa Nacional por Amostra de Domicílios (PNAD) (BRASIL, 2018a), o analfabetismo no Brasil atinge 6,8 \% da população com mais de 15 anos de idade, somando 11,3 milhões de analfabetos. 
Seção: Políticas públicas - Ensaio dissertativo

Outro indicador preocupante diz respeito ao analfabetismo funcional. Conforme o Anuário Brasileiro da Educação Básica (2019), o Indicador de Alfabetismo Funcional (INAF) aponta que $29 \%$ da população brasileira de 15 a 64 são analfabetos funcionais (CRUZ; MONTEIRO, 2019). Os analfabetos funcionais abrangem as pessoas que não leem (analfabetos) e as que são capazes de lidar com textos curtos, como bilhetes e anúncios (nível rudimentar).

Os dados sobre a distorção idade-série, a defasagem de mais de dois anos entre a idade adequada e o ano em que o aluno está cursando, especialmente nos anos finais do Ensino Fundamental e do Ensino Médio, cujos índices nacionais, em 2018, alcançaram 24,7\% e 28,2\%, respectivamente, repercutem nas matrículas da EJA. Muitos alunos em distorção idade-série migram para a modalidade e acabam compondo um perfil mais jovem, observando-se que $32 \%$ das matrículas situam-se na faixa etária abaixo de 20 anos (BRASIL, 2018a).

Quanto aos índices de escolaridade, 53,4 milhões de pessoas de 25 anos ou mais de idade (33,1\%) não concluíram o Ensino Fundamental, e 70,3 milhões de pessoas de 25 anos ou mais de idade (52,6\%) não concluíram a Educação Básica. Desse contingente, de acordo com os dados do censo escolar 2018, divulgados pelo Instituto Nacional de Estudos e Pesquisas Nacionais Anísio Teixeira (INEP), apenas 3.545.988 alunos estão frequentando a Educação de Jovens e Adultos (Ensino Fundamental e Médio), evidenciando uma tendência de queda nas matrículas, comparando-se, por exemplo, com ano de 2008, que contabilizou 4.945.424 matrículas (CRUZ; MONTEIRO, 2019), estabelecendo a diferença de 1.399.436 alunos.

A oferta de Educação Profissional Integrada à EJA alcançou o índice de 0,3\% das matrículas no Ensino Fundamental e 2,9\% no Ensino Médio no ano de 2018 (CRUZ; MONTEIRO, 2019), bastante distante dos $25 \%$ planejados na meta 10 do Plano Nacional de Educação (BRASIL, 2014).

A institucionalização da EJA proporcionou, comprovadamente, maior acesso à educação para os jovens e adultos que não estudaram ou sofreram interrupção no seu percurso escolar. No entanto, ainda há muito para avançar no atendimento das diferentes necessidades de aprendizagens e, dessa forma, consolidar a oferta de educação de qualidade para todos.

\section{PROGRAMAS FEDERAIS VOLTAdos PARA A EDUCAÇÃo DE JOVENS E ADULTOS}

Sendo a educação um compromisso de todos e de responsabilidades compartilhadas ditadas pela Constituição Federal (BRASIL, 1988) e pela Lei de Diretrizes e Bases da Educação Nacional (BRASIL, 1996b), o governo federal tomou iniciativas por meio de programas para elevação dos índices de alfabetização, taxa de escolarização e formação profissional de jovens e 
Seção: Políticas públicas - Ensaio dissertativo

adultos. Especificamente sobre a alfabetização de jovens e adultos, a execução dos programas foi efetivada por estados e municípios, com apoio do governo federal.

Os programas federais visam a equacionar as desigualdades regionais, evidenciadas na discrepância dos índices de analfabetismo por região do país, com o Sudeste e o Sul apresentando $3,5 \%$ e $3,4 \%$, respectivamente, de analfabetos, e o Nordeste, 13,8\% (CRUZ; MONTEIRO, 2019). Para tanto, procuram ampliar o acesso da população à Educação Profissional no país, beneficiando também os jovens e adultos com baixa escolaridade.

\subsection{FUNDAÇÃO NACIONAL PARA EDUCAÇÃO DE JOVENS E ADULTOS}

A Fundação Nacional para Educação de Jovens e Adultos (EDUCAR) foi criada em 1985 e regulamentada em 1986, em substituição ao extinto MOBRAL, a qual tinha como "objetivo promover a execução de programas de alfabetização e de educação básica não-formais, destinados aos que não tiveram acesso à escola ou que dela foram excluídos prematuramente" (BRASIL, 1986).

A EDUCAR, para Haddad e Di Pierro (2000), embora criada à sombra do MOBRAL, valeu-se, inicialmente, da estrutura deste, inclusive de funcionários, mas apresentou propostas inovadoras, assumiu a coordenação do Ensino Supletivo, a formação de professores e a produção de material didático, ampliando suas funções.

\footnotetext{
Se em muitos sentidos a Fundação Educar representou a continuidade do MOBRAL, devem-se computar como mudanças significativas a sua subordinação à estrutura do MEC e a transformação em órgão de fomento e apoio técnico, em vez de instituição de execução direta. Houve uma relativa descentralização das suas atividades e a Fundação apoiou técnica e financeiramente algumas iniciativas inovadoras de educação básica de jovens e adultos conduzidas por prefeituras municipais ou instituições da sociedade civil. (HADDAD; DI PIERRO, 2000, p. 120).
}

Com as mudanças do cenário político em decorrência da eleição de Fernando Collor de Mello para a presidência do país e a adoção de medidas de enxugamento de gastos, em 1990, a Fundação Educar teve suas atividades encerradas (FRIEDRICH et al, 2010).

\subsection{PROGRAMA ALFABETIZAÇÃO SOLIDÁRIA}

O Programa Alfabetização Solidária (PAS) foi criado em 1997 e desenvolvido pelo Conselho da Comunidade Solidária do Governo Federal, direcionado para jovens na faixa etária de 12 a 18 anos, embora também aceitasse a matrícula de adultos, de regiões e municípios com maior índice de analfabetismo, inicialmente no Nordeste e no Norte.

O programa do governo federal, capitaneado pela então primeira dama Ruth Vilaça Correia Leite Cardoso, estabeleceu parcerias com empresas, universidades e prefeituras. Os 
Seção: Políticas públicas - Ensaio dissertativo

alfabetizadores eram jovens do próprio município que cursavam o ensino médio, magistério ou a $8^{\mathrm{a}}$ série do ensino fundamental. Os mesmos participavam de um curso de capacitação, recebiam bolsas como remuneração e podiam atuar somente num período equivalente a um semestre, gerando rotatividade no grupo de alfabetizadores. O objetivo era alfabetizar os jovens, prioritariamente, e os adultos, em 6 meses, sendo atendidos, no período de 1997 até 2002, em torno de 1.500.000 alunos, segundo relatórios de acompanhamento do próprio programa.

Às universidades, cabia a função de coordenar as atividades de alfabetização, formação dos alfabetizadores, avaliação e acompanhamento do processo. A logística necessária, insumos e merenda escolar ficavam a cargo das prefeituras locais.

O programa foi duramente criticado por suas finalidades, operacionalização e pela qualidade dos resultados obtidos. Nesse sentido, Di Pierro (2005) apresenta algumas considerações:

[...] o governo federal conferiu lugar marginal à educação básica de jovens e adultos na hierarquia de prioridades da reforma e da política educacional, fechou o único canal de diálogo então existente com a sociedade civil organizada - a Comissão Nacional de Educação de Jovens e Adultos (CNEJA) - e, por meio do programa Alfabetização Solidária, remeteu para a esfera da filantropia parcela substancial da responsabilidade pública pelo enfrentamento do analfabetismo (DI PERRO, 2005, p. 1128).

A extinção do PAS coincidiu com o término do mandato do ex-presidente Fernando Henrique Cardoso e do exercício do cargo de primeira dama Ruth Vilaça Correia Leite Cardoso, que era a propulsora e responsável pelo programa.

\subsection{PROGRAMA BRASIL ALFABETIZADO}

O Programa Brasil Alfabetizado (PBA) foi instituído em 2003 por meio da Resolução n ${ }^{\circ}$ 018, de 10 de julho de 2003 (BRASIL, 2003). Tinha por objetivo alfabetizar jovens a partir dos quinze anos, de maneira descentralizada. Abrangia todo o território nacional, com o atendimento prioritário a 1.928 municípios que apresentam taxa de analfabetismo igual ou superior a $25 \%$. Desse total, $90 \%$ localizavam-se na região Nordeste.

O PBA enfrentou também severas críticas por manter uma estrutura de funcionamento semelhante às campanhas de alfabetização do passado, por sua restrita abrangência e não ter vínculo com o sistema formal de educação (DI PIERRO; HADDAD, 2015). 
O Programa Nacional de Integração da Educação Profissional com A Educação Básica na Modalidade de Educação de Jovens e Adultos (PROEJA) foi criado pelo Decreto ${ }^{\circ}$. 5.478, de 24 de junho de 2005, sendo pensado inicialmente para o Ensino Médio, como oportunidade da conclusão da educação básica e formação profissional àqueles que não tiveram acesso ao ensino médio na idade regular, sendo efetivado majoritariamente pela Rede Federal de Educação Profissional, Científica e Tecnológica, que inclui Institutos Federais de Educação, Ciência e Tecnologia; Centros Federais de Educação Tecnológica; e Escolas Técnicas Vinculadas às Universidades Federais.

Em 2006, a abrangência do PROEJA foi ampliada, por meio do Decreto n ${ }^{\circ} .5 .840$, de 13 de julho de 2006 (BRASIL, 2006), voltando-se para a Educação Básica (EJA Ensino Fundamental e Médio), ofertando-se cursos de Educação Profissional Técnica, integrada ou concomitante ao ensino médio e qualificação profissional, incluindo a formação inicial e continuada integrada ou concomitante aos ensinos fundamental e médio.

Ainda foram criados outros programas, como o Programa Mulheres Mil, para formação profissional e tecnológica de cerca de mil mulheres desfavorecidas das regiões Nordeste e Norte, executado pelas instituições da Rede Federal; o Programa Nacional de Inclusão de Jovens (ProJovem Urbano), com o objetivo de elevar a escolaridade de jovens com idade entre 18 e 29 anos, que saibam ler e escrever e não tenham concluído o ensino fundamental, com o suporte financeiro aos participantes condicionado à $75 \%$ de frequência; e Rede Nacional de Certificação Profissional e Formação Inicial e Continuada (Certific), para reconhecimento de saberes e emissão certificação profissional.

\subsection{PROGRAMA NACIONAL DE ACESSO AO ENSINO TÉCNICO E EMPREGO}

O Programa Nacional de Acesso ao Ensino Técnico e Emprego (PRONATEC) está regulamentado pela Lei Federal $n^{\circ} 12.513 / 2011$, que tem por objetivo ampliar a oferta de cursos de Educação Profissional e Tecnológica (EPT), por meio de programas, projetos e ações de assistência técnica e financeira, funciona através do regime de parceria com as redes federais, estaduais, distrital e municipais de educação profissional e tecnológica, com os Serviços Nacionais de Aprendizagem (SENAI, SENAC, SENAR E SENAT) e com instituições da rede privada. Para a modalidade EJA, existe o PRONATEC EJA, oferecendo a oportunidade de formação em cursos de Educação Profissional e Tecnológica (EPT) e uma bolsa formação.

As iniciativas do governo federal arroladas vão ao encontro do Plano Nacional de Educação (2014-2024), que prevê ampliar a oferta de Educação Profissional Tecnológica (EPT), articulada com a educação básica, alcançando pelo menos $25 \%$ da oferta da matrícula de EJA 
Seção: Políticas públicas - Ensaio dissertativo

(meta 10), tornando-se a qualificação profissional de trabalhadores uma das prioridades da política federal de EJA na segunda década do milênio (DI PIERRO; HADDAD, 2015). A criação e a implementação de programas federais de Educação Profissional direcionados a jovens e adultos fizeram parte do Plano de Expansão da Rede Federal de Educação Profissional e Tecnológica, atendendo às demandas de aprendizagens, à necessidade de formação de mão de obra e da sua permanente qualificação.

No entanto, a oferta da EJA integrada à Educação Profissional não pode ser pensada privilegiando a qualificação para o trabalho em detrimento da formação básica. Para Ramos (2010), o desafio reside na construção de um currículo capaz de integrar os conhecimentos gerais e os específicos da Educação Profissional. Dessa forma, não se pode correr o risco de reduzir um currículo de formação profissional às necessidades de mercado, render-se a processos de qualificação aligeirados, norteados pela lógica capitalista de formação de mão de obra como objetos e não sujeitos de um sistema de produção.

\section{CONSIDERAÇÕES FINAIS}

A trajetória das iniciativas educacionais destinadas a jovens e adultos no Brasil atravessa mais de quinhentos (500) anos da história, assim como a ausência de acesso ou acesso tardio ao mundo das letras e dos números acompanha a população mais desfavorecida do nosso país. Os contextos culturais, sociais, econômicos e políticos dos diferentes períodos históricos deixaram suas marcas, delineando ações, projetos, programas e políticas educacionais que se manifestaram como reducionistas, subordinadas aos interesses econômicos, alienantes, compensatórias, e, por último, uma aproximação ao respeito da concepção de educação como direito humano universal, para "o pleno desenvolvimento da personalidade humana." (ONU BRASIL, 1948).

Há que se considerar também que, desde o Brasil Colônia até o presente, o analfabetismo foi acentuado no país, atualmente atingindo $7 \%$ da população de 15 anos ou mais (CRUZ; MONTEIRO, 2019), e que dificilmente será erradicado até 2024, como consta na meta 9 do Plano Nacional de Educação (BRASIL, 2014). A discussão sobre erradicação do analfabetismo remete a outras questões como a concepção de alfabetização, a necessidade de integração dos processos de alfabetização com as demais etapas da Educação Básica e também a necessidade de enfrentamento do analfabetismo funcional, estimado em 29\% no país (CRUZ; MONTEIRO, 2019).

A formação profissional acompanha a evolução histórica da EJA. O jovem ou adulto, com atraso escolar ou com baixa taxa de escolaridade, busca, nos processos de escolarização, também a formação profissional, pois muitos já estão inseridos no mercado do trabalho ou 
Seção: Políticas públicas - Ensaio dissertativo

precisam se inserir para garantir a subsistência. Os planos nacionais de educação expressam essa vertente nas metas destinadas à EJA (BRASIL, 2001a; 2014). Porém, na prática, encontra-se uma formação profissional aligeirada, restrita a habilidades básicas necessárias para o desempenho de funções consideradas mais simples, condizentes com uma remuneração mais baixa.

Incorporando os princípios e fundamentos discutidos e endossados no contexto internacional em relação à EJA, a educação configura-se como um direito, independentemente da idade, que precisa ser viabilizado por oportunidades amplas e para além do acesso e da permanência na escola (GADOTTI, 2009), superando igualmente a ideia de caráter compensatório para se ampliar e consolidar como possibilidade de continuidade dos estudos, de aprender ao longo da vida diante dos tempos pós-modernos que requerem atualização permanente.

Os desafios presentes e futuros para a Educação de Jovens e Adultos se equilibram diante dos avanços inegavelmente alcançados, que abarcam a institucionalização, a concepção, a efetivação, o financiamento e os sinais de alerta, advindos das análises dos indicadores educacionais e dos estudos sobre as conjunturas da modalidade, que constataram ausência de programas abrangentes de alfabetização, retração nas matrículas, pouco progresso na elevação dos índices de alfabetização e taxa de escolaridade, crescimento do analfabetismo funcional, oferta de formação profissional deficitária ou ausência, o currículo pensado e executado nos moldes do ensino regular, a acomodação do Estado e o silêncio dos movimentos sociais.

Diante do exposto, pensar e discutir os rumos da Educação de Jovens e Adultos representa hoje uma situação de emergencialidade, somada ao atual panorama brasileiro de crise e mudanças políticas. Embora haja muitos aspectos da perspectiva tecnicista que são úteis ao desenvolvimento profissional, a educação também precisa contribuir para a formação integral do sujeito e, especialmente, atingir expectativas pessoais e alianças interpessoais dos jovens e adultos. E, nesse sentido, o pensamento em prol da EJA e sua qualidade de ensino exigem flexibilidade, maturidade psicológica, criatividade e complexidade cognitiva, na medida em que se busca atender às características e qualidades de desenvolvimento e de cultura dos jovens e adultos, às suas histórias de vida e contextos sociais.

\section{REFERÊNCIAS}

BRASIL. Constituição Política do Império do Brasil. Elaborada por um Conselho de Estado e outorgada pelo Imperador D. Pedro I, em 25.03.1824. Brasília, 1824. Disponível em: http://www.planalto.gov.br/ccivil_03/Constituicao/Constituicao24.htm. Acesso em: 30 mar. 2019. 
BRASIL. Lei no 16 de 12 de agosto de 1834. Faz algumas alterações e adições à Constituição Política do Império. Disponível em: //http://www.planalto.gov.br/ccivil_03/leis/lim/LIM16.htm. Acesso em: 30 mar. 2019.

BRASIL. Decreto $n^{0}$ 1.331-A, de 17 de fevereiro de 1854. Aprova o Regulamento para a reforma do ensino primário e secundário do Município da Corte. 1854. Disponível em: http://www2.camara.leg.br/legin/fed/decret/1824-1899/decreto-1331-a-17-fevereiro-1854590146-publicacaooriginal-115292-pe.html. Acesso em: 15 mar. 2019.

BRASIL. Decreto no 7.031-A, de 6 de setembro de 1878. Cria cursos noturnos para adultos nas escolas públicas de instrução primária do $1^{\circ}$ grau do sexo masculino do município da Corte. 1878 . Disponível em: http://www2.camara.leg.br/legin/fed/decret/1824-1899/decreto-7031-a-6setembro-1878-548011-publicacaooriginal-62957-pe.html. Acesso em: 15 mar. 2019.

BRASIL. Decreto no 7.247, de 19 de abril de 1879. Reforma o ensino primário e secundário no município da Corte e o superior em todo o Império. 1879. Disponível em: http://www2.camara.leg.br/legin/fed/decret/1824-1899/decreto-7247-19-abril-1879-547933pub.licacaooriginal-62862-pe.html. Acesso em: 15 mar. 2019

BRASIL. Constituição da República dos Estados Unidos do Brasil, de 24 de fevereiro de $1891 . \quad 1891 . \quad$ Disponível em: http://www.planalto.gov.br/ccivil_03/constituicao/constituicao91.htm. Acesso em: 1 mar. 2019.

BRASIL. Constituição da República dos Estados Unidos do Brasil, de 16 de julho de 1934. Brasília: Presidência da República, 1934. Disponível em: http://www.planalto.gov.br/ccivil_03/constituicao/constituicao34.htm. Acesso em: 8 mar. 2019.

BRASIL. Constituição da República dos Estados Unidos do Brasil, de 18 de setembro de 1946. Brasília: Presidência da República, 1946. Disponível em: http://www.planalto.gov.br/ccivil_03/constituicao/constituicao46.htm. Acesso em: 8 mar. 2019.

BRASIL. Ministério da Educação. Lei de Diretrizes e Bases da Educação Nacional no 4.024/61, de 20 de dezembro de 1961. Fixa as Diretrizes e Bases da Educação Nacional. Brasília: Ministério da Educação,1961. Disponível em: https://www2.camara.leg.br/legin/fed/lei/1960-1969/lei-4024-20-dezembro-1961-353722publicacaooriginal-1-pl.html. Acesso em: 15 mar. 2019.

BRASIL. Decreto $\mathbf{n}^{\mathbf{0}}$ 53.465, de 21 de janeiro de 1964. Institui o Programa Nacional de Alfabetização do Ministério da Educação e Cultura e dá outras providências. Brasília: MEC, 1964. Disponível em: https://www2.camara.leg.br/legin/fed/decret/1960-1969/decreto-5346521-janeiro-1964-393508-publicacaooriginal-1-pe.html. Acesso em: 15 mar. 2019.

BRASIL. Constituição da República dos Estados Unidos do Brasil, de 24 de janeiro de 1967. Brasília, 1967a. Disponível em: http://www.planalto.gov.br/ccivil_03/Constituicao/Constituicao67.htm. Acesso em: 8 mar. 2019.

BRASIL. Lei $n^{0}$ 5.379, de 15 de dezembro de 1967. Prove sobre a alfabetização funcional e a educação continuada a adolescentes e adultos. Brasília, 1967b. Disponível em: http://www.planalto.gov.br/ccivil_03/LEIS/1950-1969/L5379.htm. Acesso em: 8 mar. 2019. 
BRASIL. Ministério da Educação. Lei de Diretrizes e Bases da Educação no 5692/71, de 12 de agosto de 1971. Fixa diretrizes e bases para o ensino de $1^{\circ}$ e $2^{\circ}$ graus e dá outras providências. Brasília: MEC, 1971. Disponível em: https://www2.camara.leg.br/legin/fed/lei/1970-1979/lei5692-11-agosto-1971-357752-publicacaooriginal-1-pl.html. Acesso em: 8 mar. 2019.

BRASIL. Decreto $\mathbf{n}^{\circ}$ 92.374, de 6 de fevereiro de 1986. Aprova o Estatuto de Fundação Nacional para Educação de Jovens e Adultos. Brasília: EDUCAR, 1986. Disponível em: https://www2.camara.leg.br/legin/fed/decret/1980-1987/decreto-92374-6-fevereiro-1986442863-publicacaooriginal-1-pe.html. Acesso em: 31 mar. 2019.

BRASIL. Constituição do Brasil de 1988. Brasília: Presidência da República, 1988. Disponível em: http://www.planalto.gov.br/ccivil_03/constituicao/constituição.htm. Acesso em: 22 jul. 2019.

BRASIL. Instituto Brasileiro de Geografia e Estatística. Pesquisa Nacional por Amostra de Domicílios: síntese dos indicadores de 1996. Brasília: IBGE, 1996a. Disponível em: https://ww2.ibge.gov.br/home/estatistica/populacao/condicaodevida/indicadoresminimos/notasi ndicadores.shtm. Acesso em: 10 out. 2019.

BRASIL. Ministério da Educação. Lei de Diretrizes e Bases da Educação Nacional n 9394/96, de 20 de dezembro de 1996. Estabelece as diretrizes e bases da educação nacional. Brasília: MEC, 1996b. Disponível em: http://www.planalto.gov.br/ccivil_03/LEIS/L9394.htm. Acesso em: 30 mar. 2019.

BRASIL. Conselho Nacional de Educação. Parecer CNE/CEB no 11/2000, de 10 de maio de 2000. Institui as Diretrizes Curriculares Nacionais para a Educação de Jovens e Adultos. Brasília, CNE, 2000a. Disponível em: http://portal.mec.gov.br/secad/arquivos/pdf/eja/legislacao/parecer_11_2000.pdf. Acesso em 22 jan. 2019.

BRASIL. Conselho Nacional de Educação. Resolução CNE/CEB no 1/2000, de 5 de julho de 2000. Estabelece as Diretrizes Curriculares Nacionais para a Educação de Jovens e Adultos. Brasília, DF, 2000b. Disponível em: http://portal.mec.gov.br/cne/arquivos/pdf/CEB012000.pdf. Acesso em: 22 out. 2018.

BRASIL. Plano Nacional de Educação. Lei n⿳ 10.172, de 09 de janeiro de 2001. Aprova o Plano Nacional de Educação e dá outras providências. Brasília, DF: Presidência da República, 2001a. Disponível em: http://www.planalto.gov.br/ccivil_03/leis/leis_2001/110172.htm. Acesso em: 10 out. 2018.

BRASIL. Ministério da Educação. Proposta Curricular para a Educação de Jovens e Adultos: primeiro segmento do ensino fundamental. Secretaria de Educação Fundamental. Brasília: MEC, 2001b. Disponível em: http://portal.mec.gov.br/secad/arquivos/pdf/eja/propostacurricular/primeirosegmento/propostac urricular.pdf. Acesso em: 8 out. 2018.

BRASIL. Ministério da Educação. Proposta Curricular para a Educação de Jovens e Adultos: segundo segmento do ensino fundamental: $5^{\mathrm{a}}$ a $8^{\mathrm{a}}$ série. Secretaria de Educação Fundamental. Brasília: MEC, 2002. Disponível em: http://portal.mec.gov.br/secad/arquivos/pdf/eja_livro_01.pdf. Acesso em: 8 out. 2018. 
Seção: Políticas públicas - Ensaio dissertativo

BRASIL. Resolução CD/FNDE $\mathbf{n}^{\circ} 018$ de 10 de julho de 2003. Estabelece orientações e diretrizes para a assistência financeira suplementar a projetos educacionais no âmbito do Programa Brasil Alfabetizado, para o ano de 2003. Brasília, 2003. Disponível em: ftp://ftp.fnde.gov.br/web/resolucoes_2003/res018_10072003.pdf. Acesso em: 27 mar. 2019.

BRASIL. Decreto $\mathbf{n}^{\mathbf{0}}$ 5.840, de 13 de julho de 2006. Institui, no âmbito federal, o Programa Nacional de Integração da Educação Profissional com a Educação Básica na Modalidade de Educação de Jovens e Adultos - PROEJA, e dá outras providências. Brasília, 2006. Disponível em: http://www.planalto.gov.br/ccivil_03/_ato2004-2006/2006/decreto/d5840.htm. Acesso em: 15 mar. 2019.

BRASIL. Lein ${ }^{0}$ 11.494, de 20 de junho de 2007. Regulamenta o Fundo de Manutenção e Desenvolvimento da Educação Básica e de Valorização dos Profissionais da Educação. Brasília, 2007. Disponível em: http://www.planalto.gov.br/ccivil_03/_Ato20072010/2007/Lei/L11494.htm. Acesso em: 29 mar. 2019.

BRASIL. Lei $\mathbf{N}^{\mathbf{0}}$ 11.741, de 16 de julho de 2008. Altera dispositivos da Lei no 9.394, de 20 de dezembro de 1996. Estabelece as diretrizes e bases da educação nacional, para redimensionar, institucionalizar e integrar as ações da educação profissional técnica de nível médio, da educação de jovens e adultos e da educação profissional e tecnológica. Brasília, 2008. Disponível em: http://www.planalto.gov.br/ccivil_03/_Ato2007-2010/2008/Lei/L11741.htm\#art1. Acesso em: 10 jul. 2019.

BRASIL. Conselho Nacional de Educação. Parecer CNE/CEB no 23/2008, aprovado em 8 de outubro de 2008. Institui Diretrizes Operacionais para a Educação de Jovens e Adultos - EJA nos aspectos relativos à duração dos cursos e idade mínima para ingresso nos cursos de EJA; idade mínima e certificação nos exames de EJA; e Educação de Jovens e Adultos desenvolvida por meio da Educação a Distância. Brasília, CNE, 2008. Disponível em; http://portal.mec.gov.br/cne/arquivos/pdf/2008/pceb023_08.pdf. Acesso em: 28 mar. 2019.

BRASIL. Lei $\mathbf{n}^{0}$ 11.947, de 16 de junho de 2009. Dispõe sobre o atendimento da alimentação escolar e do Programa Dinheiro Direto na Escola aos alunos da educação básica e dá outras providências. Brasília, 2009. Disponível em: http://www.planalto.gov.br/ccivil_03/_Ato20072010/2009/Lei/L11947.htm. Acesso em: 15 mar. 2019.

BRASIL. Resolução CD/FNDE $n^{\circ} n^{0}$ 51, de 16 de setembro de 2009 (Alterada pela Resolução n 22, de 7 de junho de 2013). Dispõe sobre o Programa Nacional do Livro Didático para Educação de Jovens e Adultos (PNLD EJA). Brasília, 2009.Disponível em: https://www.fnde.gov.br/index.php/acesso-a-informacao/institucional/legislacao/item/3360resolu\%C3\%A7\%C3\%A3o-cd-fnde-n\%C2\%BA-51-16-de-setembro-de-2009. Acesso em: 27 mar. 2019

BRASIL. Conselho Nacional de Educação. Parecer CNE/CEB n $\mathbf{n}^{\mathbf{4}}$ 4/2010, aprovado em 9 de março de 2010. Diretrizes Nacionais para a oferta de educação para jovens e adultos em situação de privação de liberdade nos estabelecimentos penais. Brasília: CNE, 2010a. Disponível em: http://portal.mec.gov.br/conselho-nacional-de-educacao/atos-normativos--sumulas-pareceres-eresolucoes. Acesso em: 30 mar. 2019.

BRASIL. Conselho Nacional de Educação. Parecer CNE/CEB n ${ }^{\mathbf{0}}$ 6/2010, aprovado em 7 de abril de 2010 - Reexame do Parecer CNE/CEB n 23/2008, que institui Diretrizes Operacionais para a Educação de Jovens e Adultos - EJA, nos aspectos relativos à duração dos cursos e idade 
mínima para ingresso nos cursos de EJA; idade mínima e certificação nos exames de EJA; e Educação de Jovens e Adultos desenvolvida por meio da Educação a Distância. Brasília: CNE, 2010b. Disponível em: http://portal.mec.gov.br/conselho-nacional-de-educacao/atosnormativos--sumulas-pareceres-e-resolucoes. Acesso em: 28 mar. 2019.

BRASIL. Conselho Nacional de Educação. Parecer CNE/CEB n ${ }^{\mathbf{0}} \mathbf{7 / 2 0 1 0}$, aprovado em 7 de abril de 2010. Diretrizes Curriculares Nacionais Gerais para a Educação Básica. Brasília: CNE, 2010c. Disponível em: http://portal.mec.gov.br/conselho-nacional-de-educacao/atosnormativos--sumulas-pareceres-e-resolucoes. Acesso em: 28 mar. 2019.

BRASIL. Conselho Nacional de Educação. Resolução CNE/CEB n 2/2010, de 19 de maio de 2010. Dispõe sobre as Diretrizes Nacionais para a oferta de educação para jovens e adultos em situação de privação de liberdade nos estabelecimentos penais. Brasília: CNE, 2010d. Disponível em: http://portal.mec.gov.br/index.php?option=com_docman\&view=download\&alias=5142rceb002-10\&category_slug=maio-2010-pdf\&Itemid=30192. Acesso em: 2 mar. 2019.

BRASIL. Conselho Nacional de Educação. Resolução CNE/CEB no 3/2010, de 5 de julho de 2010. Institui Diretrizes Operacionais para a Educação de Jovens e Adultos nos aspectos relativos à duração dos cursos e idade mínima para ingresso nos cursos de EJA; idade mínima e certificação nos exames de EJA; e Educação de Jovens e Adultos desenvolvida por meio da Educação a Distância. Brasília: CNE. 2010e. Disponível em: http://portal.mec.gov.br/index.php?option=com_docman\&view=download\&alias=5642rceb003-10\&category_slug=junho-2010-pdf\&Itemid=30192. Acesso em: 2 mar. 2019.

BRASIL. Lei $\mathbf{n}^{\mathbf{0}}$ 12.513, de 26 de Outubro de 2011. Institui o Programa Nacional de Acesso ao Ensino Técnico e Emprego. Brasília: PRONATEC, 2011. Disponível em: http://www.planalto.gov.br/ccivil_03/_Ato2011-2014/2011/Lei/L12513.htm. Acesso em: 15 mar. 2019.

BRASIL. Resolução CD/FNDE n⿳ 22/2013, de 07 de junho de 2013. Altera o $\S 3^{\circ}$ do art. $6^{\circ}$ da Resolução $n^{\circ} 42$, de 28 de agosto de 2012, e o $\S 4^{\circ}$ do art. $1^{\circ}$ da Resolução $n^{\circ} 51$, de 16 de setembro de 2009, que dispõem sobre o Programa Nacional do Livro Didático para a Educação Básica e a Educação de Jovens e Adultos. Brasília: FNDE, 2013. Disponível em: https://www.fnde.gov.br/acesso-a-informacao/institucional/legislacao/item/4600-resolução-cdfnde-nº-22,-de-7-de-junho-de-2013. Acesso em: 27 mar. 2019.

BRASIL. Plano Nacional de Educação. Lei no 13.005, de 14 de julho de 2014. Aprova o Plano Nacional de Educação e dá outras providências. Brasília, DF: Presidência da República, 2014. Disponível em: http://www.planalto.gov.br/ccivil_03/_Ato2011-2014/2014/Lei/L13005.htm. Acesso em: 10 out. 2018.

BRASIL. Lei $\mathbf{n}^{\mathbf{0}}$ 13.632, de 6 de março de 2018. Altera a Lei ${ }^{\circ}$ 9.394, de 20 de dezembro de 1996 (Lei de Diretrizes e Bases da Educação Nacional), para dispor sobre educação e aprendizagem ao longo da vida. Brasília: LDB, 2018b. Disponível em: http://www.planalto.gov.br/ccivil_03/_Ato2015-2018/2018/Lei/L13632.htm. Acesso em: 29 mar. 2019.

BRASIL. Instituto Brasileiro de Geografia e Estatística. Pesquisa Nacional por Amostra de Domicílios: Síntese dos indicadores de 2018. Brasília: IBGE, 2018a. Disponível em: https://biblioteca.ibge.gov.br/visualizacao/livros/liv101576_informativo.pdf. Acesso em: 13 nov. 2019. 
CRUZ, P.; MONTEIRO L. (org.). Anuário da Educação Básica Brasileira. São Paulo: Editora Moderna, 2019.

DI PIERRO, M. C.; JOIA, O.; RIBEIRO, V. M. Visões da educação de jovens e adultos no Brasil. Caderno Cedes, n. 55, p. 58-77, 2001.

DI PIERRO, M.C.; VOVIO, C.L.; ANDRADE, E.R. Alfabetização de jovens e adultos no Brasil: lições da prática. Brasília: Unesco, 2008.

DI PIERRO, M. C. Notas sobre a redefinição da identidade e das políticas públicas de educação de jovens e adultos no Brasil. Educação. \& Sociedade, v. 26, n. 92, p. 1115-1139, 2005.

DI PIERRO, M. C.; HADDAD, S. Transformações nas políticas de educação de jovens e adultos no Brasil no início do terceiro milênio: uma análise das agendas nacional e internacional. Cadernos Cedes, v. 35, n. 96, p. 197-217, 2015.

FELTRIN, T. Educação Popular no Brasil: forças que concorrem para a emergência da escola nacional. 2017.157 p. Dissertação (Mestrado em Educação) - Universidade Federal de Santa Maria, Santa Maria, 2017.

FRIEDRICH, M. et al. Trajetória da escolarização de jovens e adultos no Brasil: de plataformas de governo a propostas pedagógicas esvaziadas. In Ensaio: aval. pol. públ. Educ., Rio de Janeiro, v. 18, n. 67, p. 389-410, abr./jun., 2010.

GADOTTI, M. Educação de Adultos como Direito Humano. São Paulo: Editora e Livraria Paulo Freire, 2009.

HADDAD, S.; DI PIERRO, M. C. Escolarização de jovens e adultos. Revista Brasileira de Educação, n. 14, p. 108-130, 2000. Disponível em: http://ref.scielo.org/2hdkrw. Acesso em: 3 jan. 2019.

IRELAND, D.T. Sessenta anos de CONFINTEAs: uma retrospectiva. In: IRELAND, D. T.; SPEZIA, C.H. (org.). Educação de adultos em retrospectiva: 60 anos de CONFINTEA. Brasília: UNESCO, MEC, 2014.

MOURA, M. G. C. Educação de Jovens e Adultos: um olhar sobre sua trajetória histórica. Curitiba: Educarte, 2003.

PAIVA, J. M. de. Educação Jesuítica no Brasil Colonial. In: LOPES, E. M. T. et al (org.). 500 Anos de Educação no Brasil. Belo Horizonte: Autêntica, 2000. p. 43-59.

ONU BRASIL. Declaração Universal dos Direitos Humanos. 1948. Disponível em: https://nacoesunidas.org/direitoshumanos/declaracao/. Acesso em: 28 mar. 2019.

RAMOS, M. N. Implicações Políticas e Pedagógicas da EJA integrada à Educação Profissional. Educação e Realidade, v. 35, n.1, p. 65-85, 2010. Disponível em: https://seer.ufrgs.br/educacaoerealidade/article/view/11029. Acesso em: 19 jul. 2019.

RUMMERT, S. M. A educação de jovens e adultos trabalhadores brasileiros no século XXI: o "novo" que reitera antiga destituição de direitos. Revista de Ciências da Educação, Lorena, SP,
n.
2 ,
p.
$35-50$,
2007.
Disponível
em: 
Seção: Políticas públicas - Ensaio dissertativo

https://pdfs.semanticscholar.org/f134/e2dcbeeb8785d0ae17de80fd889c00e84f32.pdf. Acesso em: 20 dez. 2019. 